\title{
The World in a Journal
}

\author{
David Damrosch, for the editors \\ Harvard University \\ ddamrosc@fas.harvard.edu
}

To establish a new journal entails thinking seriously about the challenges as well as the opportunities for scholarly work in the field, and this is especially true in a rapidly evolving field such as the study of World Literature. Amid the excitement of the expansion of comparative studies to a global scale, difficult choices have to be made in deciding what dimensions of the world's vast literary production to showcase within the 125 pages available in each of our issues, and the choices extend to method and perspective as well as material. What kinds of work should our readers expect to find in our pages? What thematic or other forms should our quarterly issues take, and what kinds of work should people send us? What interventions will the Journal of World Literature seek to make in the field, and in literary studies more generally?

The challenges involved in planning our issues would be considerable enough even if it were merely a matter of deciding whether to accept an essay on translations of Tagore instead of one on Murakami's reworking of Kafka. The difficulties are considerably increased by the deep antinomies that underlie comparative and world literary studies today. These divisions produce widely divergent kinds of work, sparking sometimes sharp debates between proponents of differing political views or theoretical or methodological perspectives. Many of these antinomies have been percolating for years in the fields of comparative literature, postcolonial studies, literary theory, and Translation Studies; they come to the fore with renewed force once "world literature" no longer signifies primarily a select canon of Western European masterpieces and their classical antecedents. The $J W L$ is intended to provide a forum in which our contributors can find new ways to address the cultural, political, and philological challenges of literary study in a global age.

Even to identify the antinomies underlying the field today involves making debatable choices that may be skewed in favor of some perspectives over others. If, as the saying goes, the world is divided into two groups-those who divide the world into two groups and those who don't - this formulation already locates itself (however ironically) in the first of these categories. Yet cer- 
tain key antinomies can be identified that most people would acknowledge, however they choose to address them. Several rifts in the landscape of today's world literary studies are particularly contentious and in need of fresh thought: between cosmopolitan universalism and national or local cultural specificity; between postcolonial and global studies; between work with (untranslatable?) original languages and work in translation; and between aesthetics and politics as the fundamental ground of study. All of these antinomies have become the subjects of widespread debate in the field, and to these four oppositions could be added a fifth, not as often discussed but also highly significant: between earlier eras and the modern or contemporary period. Mads Rosendahl Thomsen has argued that earlier and contemporary literatures comprise two distinct and almost separate systems; can we even speak of "world literature" in the singular at all, whether we are thinking temporally, regionally, aesthetically, or politically?

These are real divisions, and they can't be ignored. Different people have deeply held commitments on one side or the other of each of these equations, or at one or another point along a spectrum between each pair of opposed terms. If the $J W L$ is to be a forum for airing and advancing these debates, this will sometimes involve publishing integrative work that shows how seemingly opposed terms can be combined, and at other times presenting work that takes a stand and advocates a given approach or perspective. An analogy for the latter option can be made to the "language anxiety" that Robert Young has identified as pervasive among colonial and postcolonial writers: do they adopt the language of their present or recent imperial masters, or do they instead employ a local vernacular? Sometimes a compromise solution can be found, as with the exuberantly creolized English that Amos Tutuola developed for The Palm-Wine Drinkard, but writers have more often found themselves confronted with the necessity of making a definite choice one way or the other. As Young has remarked, either choice has its advantages and its disadvantages; his conclusion is that the most important thing is for a writer to feel and face this anxiety, dealing with it creatively rather than merely wishing it away.

Sometimes our contributors will no doubt be combining postcolonial and global perspectives, or will be working both with original texts and translations, but often they are likely to have positioned their essay within one or another perspective or approach, whether for ethical or political reasons or simply in order to delimit a topic and pursue a particular line of inquiry. Under integrative or contrastive approaches alike, we will look for nuanced work that avoids the limitations of a vague, feel-good universalism on the one hand, or on the other a Manichaean presentation of stark either/or choices culminating in the ritual slaughter of some straw figure from the opposite camp. 
Postcolonial scholars often feel that discussions of global literature lose the cultural specificity and the political edge of analyses of specific empires and post-imperial orders (Spivak, Apter), while others find in world systems theory or comparative poetics a means of reaching beyond the monolingualism of much postcolonial scholarship, thinking about literary circulation in a world dominated more by the Frankfurter Buchmesse than by any imperial regime, as Jérôme David emphasizes in the final chapter of his Spectres de Goethe. Both viewpoints will find space in the $J W L$.

As of this writing, plans have been made for the journal's first three years, emphasizing special issues developed by guest editors, with the expectation of having more open-call issues once the journal is well established and known. Taken together, our initial dozen issues represent our first approaches toward the antinomies outlined above. This inaugural issue itself shows a range of perspectives among the editors and invited contributors who have written statements of principles and have provided examples of specific studies putting principle into practice.

In their opening essay, our managing editors Omid Azadibougar and Esmaeil Haddadian-Moghaddam — the journal's primary progenitors-negotiate between Iranian specificity and global perspectives as they describe how their original idea for a journal of translation and Persian literature developed into the Journal of World Literature. Their account is grounded in opposition to an exclusivist politics of culture that they see as characteristic of authoritarian regimes.

Cultural politics can be pervasive even when not enforced by governments, as publishers, translators, reviewers, and educators collectively (if often unconsciously) create and sustain the uneven playing field separating a few dominant literary cultures from the rest. This inequality was already identified by the Danish scholar Georg Brandes in his 1899 essay "World Literature," in which he lamented the fact that

writers of different countries and languages occupy enormously different positions where their chances of obtaining worldwide fame, or even a moderate degree of recognition, are concerned. The most favorably situated are the French writers [...] But whoever writes in Finnish, Hungarian, Swedish, Danish, Dutch, Greek or the like is obviously poorly placed in the universal struggle for fame. In this competition he lacks the major weapon, a language - which is, for a writer, almost everything.

63 
Several of our contributors probe the politics of literary circulation, including Theo D'haen, who argues for greater attention to works beyond the pale of the great works of major cultures, noting that a contemporary focus on "major cultures" around the globe can still exclude works from such smaller countries as Belgium or the Netherlands as fully as had the older emphasis on European "great powers." In her essay, Gisèle Sapiro looks at the market forces that have a major effect on how works do or don't cross borders.

Whereas D'haen and Sapiro focus, like Brandes before them, on the modern circulation of texts across spatial borders, Alexander Beecroft's essay turns from space to time, making a forceful case for the need to rethink in non-Eurocentric terms the periodizations through which we organize literary history. Both time and space figure in the creating and transmission of literary canons within and across cultures, and Zhang Longxi emphasizes the importance of studying canonical works that are recognized as such in their home cultures but often not yet part of a world literary canon if they belong to non-Western literary traditions or "minor" European literatures.

Writing from Brazil, José Luís Jobim and João Cezar de Castro Rocha argue for an understanding of Latin American circulations and transculturations of European works as more active and creative than older models of peripheral reception had supposed. Satoru Hashimoto challenges the very idea that circulation should be as central in world literary studies as it is often assumed to be; he compares the foreign reception by Bertolt Brecht and Walter Benjamin of accounts of the origins of the Daodejing to the revisionist reworking of the same tales by Lu Xun in China itself.

The differences between premodern, early modern, and contemporary manifestations of World Literature aren't absolute, but they are considerable and important to understand and explore. Much World Literature scholarship today is based largely on works written within the past century or two, within what can be described as a modern "world system" (Moretti) or a "république mondiale des lettres" (Casanova). Yet even premodern literatures have almost always been written within regional and even transregional contexts, and some of the most exciting work in world literature today is being done on the literatures of premodern worlds. In her contribution, Ronit Ricci discusses the importance of attending to the very different ways in which translation has been understood and practiced in premodern times, as she shows in the case of interlinear translations from Arabic into Malay and Javanese.

The intertwined terms of translatability and untranslatability found in Ricci's essay can be compared to recent analyses of untranslatability in modern contexts, as analyzed in works such as Jacob Edmond's A Common Strangeness. Such linguistic challenges to translation can be compared in turn with the resis- 
tance of ancient texts to circulation across regional boundaries, as explored by Wiebke Denecke in her recent Classical World Literatures. She argues for work attuned to "asymmetries of the comparison of historically unrelated cultures," in an approach that "turns asymmetry and incommensurability into a key heuristic device" (300). Here premodern incommensurability becomes a cultural analog to the "untranslatability" that (pace Apter) has long been a focus in Translation Studies.

A running theme in our essays is the need to re-envision world literary studies for the future, and this theme is central to the contributions by Mads Rosendahl Thomsen and Karen L. Thornber. Thomsen outlines a series of fundamental shifts in the contemporary world and our understanding of our place in it, including new patterns of migration, the rise of the digital world, and the very question of what it is to be human. Thornber argues for the need for world literary studies to address issues of global crises that contemporary writers often explore, and to develop our analyses of such concerns on a genuinely global basis in future.

Looking ahead to our journal's own future, the $J W L$ will freely alternate between national, regional, and global emphases, with special issues planned on topics as nationally based as "Romanian World Literature" (issue 3:1) and as global as "Literary Translingualism" (issue 3:2) and "Fictions of Circulation" (issue 1:4). At an in-between scale are regionally based issues on topics such as "Scandinavian World Literature" (issue 2:1) and Arabic world literature (issue 2:2). Other issues will focus on particular fields or approaches, such as Translation Studies (issue 1:3), or on conceptual or definitional questions, such as "Ultra-minor Literatures" (issue 2:3).

It has sometimes been claimed that contemporary discussions of world literature are largely an outgrowth of (neo)liberal American multiculturalism, packaged for easy reading in sophomore-level survey courses that promote a depoliticized and tokenistic understanding of the wider world, superficially seen only in translation (Spivak). Granting that world literary studies, like the discipline of comparative literature as a whole, found particularly fertile ground in the postwar United States, the study of World Literature has never been an exclusively American phenomenon. The first journal of world literature, the Acta Comparationis Litterarum Universarum, was produced in Transylvania in $1877^{-1887}$ by Hugo Meltzl and his Hungarian colleague Samuel Brassai. The concept was debated at the turn of the twentieth century by Chinese intellectuals (see Tsu) and by Denmark's Georg Brandes. World literature began to be anthologized in Japan in the 1920s, and in the Soviet Union the Gorky Institute of World Literature embarked on an ambitious program of translation and publication as early as 1918. Today, significant journals of World Lit- 
erature include 世界文学 (World Literature), published in Beijing since 1953, Pazhuhesh-e Adabiyat-e Mo'aser-e Jahan (Research in Contemporary World Literature), published in Persian since 2002, Wielogtos (Polyphony), published in Poland since 2007, World Literature Studies published in Slovakia since 2009, and the ambitious new Korean journal Chigujŏk segye munhak (Global World Literature), whose editor Kim Jae-yong has contributed a programmatic essay in this issue. As for our own Journal of World Literature, published in the Netherlands, it has an editorial board drawn from eighteen countries, and our third issue each year will be derived from sessions of the Institute for World Literature, supported by institutional affiliates from more than two dozen countries around the world, with annual sessions held in rotation between Asia, the United States, and Europe or the Middle East.

In teaching as in scholarship, serious work in world literature involves extensive work in original languages, and world literary studies today embraces far more languages than were commonly treated in earlier comparative studies. Translation plays a valuable role as a medium of dissemination, enabling us to read and study a much wider range of work than anyone can access in original languages alone, and translation theory is now an integral part of world literary study. Translation Studies will have a significant place within the $J W L$, even as we will always (and probably predominantly) feature essays that work with original languages, as of course translation studies themselves usually do. English does have a major role today as a medium of international teaching and scholarly exchange, and is the common language for the $J W L$. Our journal has been inspired in part by Meltzl and Brassai's pioneering Acta Comparationis Universarum Litterarum, but we haven't attempted to follow the "decaglottism" of their ten official languages, an idealistic plurilingualism that—even though still limited to European languages - was a prime factor in the limited success of the Acta in reaching an international audience and surviving more than a few years. Yet within our pages, you will find extensive discussions of works read in the original, from less commonly studied languages as well as languages of global reach. Discussions of globalization today sometimes use ecological metaphors to describe rarely spoken languages as endangered species; in his inaugural essay for the Acta Comparationis, Meltzl was probably the first person ever to make this comparison. "In a time when certain animal species such as the mountain goat and the European bison are protected against extinction by elaborate and strict laws," he remarks, "the willful extinction of a human species (or its literature, which amounts to the same thing) should be impossible" (46).

Faced with declining enrollments in the humanities worldwide and the uncertainties of literature's place in a shifting mediascape, literary scholars 
themselves sometimes feel like an endangered species. At such a time, the liveliness of today's World Literature debates, and the contributions to them from many locations around the world, are a cause for celebration, as is the establishment of a new journal for this expansive and vital field. Whether you are reading these words on the page or in pixels, welcome to the Journal of World Literature. We hope that you will enjoy the stimulating range of position papers collected here, and we hope to see you again soon.

\section{Works Cited}

Apter, Emily. Against World Literature: On the Politics of Untranslatability. London: Verso, 2015.

Brandes, Georg. "World Literature," tr. Haun Saussy. In The Princeton Sourcebook in Comparative Literature, eds. David Damrosch, Natalie Melas, and Mbongiseni Buthelezi. Princeton, NJ: Princeton University Press, 2009, 61-66. First published as "Weltliteratur," in Das litterarische Echo 2:1 (1899).

Casanova, Pascale. La République mondiale des lettres. Paris: Editions du Seuil, 1999.

David, Jérôme. Spectres de Goethe: Les Métamorphoses de la "Littérature Mondiale." Paris: Les Prairies Ordinaires, 2011.

Denecke, Wiebke. Classical World Literatures: Sino-Japanese and Greco-Roman Comparisons. Oxford: Oxford University Press, 2013.

Edmond, Jacob. A Common Strangeness: Contemporary Poetry, Cross-Cultural Encounter, Comparative Literature. New York: Fordham University Press, 2012.

Meltzl, Hugo. "Present Tasks of Comparative Literature," tr. Hans-Joachim Schulz. In The Princeton Sourcebook in Comparative Literature, eds. David Damrosch, Natalie Melas, and Mbongiseni Buthelezi. Princeton, NJ: Princeton University Press, 2009, 41-49. First published in Acta Comparationis Litterarum Universarum 1 (January 1877), 179-82, and 2 (October 1877), 307-15.

Moretti, Franco. Distant Reading. London: Verso, 2013.

Spivak, Gayatri. Death of a Discipline. New York: Columbia University Press, 2003.

Thomsen, Mads Rosendahl. Mapping World Literature: International Canonization and Transnational Literatures. London: Continuum, 2008.

Tsu, Jing. "Getting Ideas about World Literature in China." Comparative Literature Studies 47:3 (2010), 290-317.

Tutuola, Amos. The Palm-Wine Drinkard. London: Faber and Faber, 1952.

Young, Robert J.C. "World Literature and Language Anxiety." In Approaches to World Literature, ed. Joachim Küpper. Berlin: Akademie, 2013, 27-38. 